\title{
Õpetaja tegevus tunnis: õpilaste hinnangud ja nende kooskõla õpetajate arusaamadega
}

\author{
Anne Okas ${ }^{\mathrm{a}}$, Marieke van der Schaaf ${ }^{\mathrm{b}}$, Edgar Krull ${ }^{\mathrm{a}}$ \\ a Tartu Ülikooli haridusteaduste instituut \\ ${ }^{b}$ Utrechti Ülikooli haridusteaduste osakond
}

\begin{abstract}
Annotatsioon
Tutvustatav uurimus on osa mahukamast õpetaja professionaalsuse avaldumist käsitlevast uurimistööst. Selle eesmärk on selgitada välja, millisena tajuvad õpilased õpetaja tegevust tunnis, sealhulgas millised on erinevused hinnangutes algajatele ja kogenud õpetajatele, ning kõrvutada neid hinnanguid õpetajate endi kujutlustega õpetamisest. Uuringus osales 314 põhikooliõpilast (6.-9. klass) ja nende 20 õpetajat, kellest kümme olid algajad ja kümme kogenud õpetajad. Õpilaste hinnangud õpetajate õpetamisviiside kohta selgitati välja küsitlusega. Selles hindasid õpilased õppimistingimuste loomist, tunnieesmärkide selgust, tunni ülesannete sisu selgust ja raskusastet, õpetaja juhendamist, kontrollimist, hoolivust ja entusiasmi. Ôpilaste hinnanguid võrreldi andmetega, mis on esitatud õpetajate reflekteerivates kirjutistes nende õpetamismeisterlikkuse kohta, samuti ainetunni kommentaaridega. Uurimistulemustest ilmnes, et õpilaste antud hinnangud õpetajate tegevusviisidele seostuvad õpetaja töökogemusega. Õpetajate endi kirjutistest ja intervjuudest ning õpilaste hinnangutest selgus, et algajate õpetajate raskusi tunni läbiviimisel märkavad ka nende õpilased. Õpilaste keskmised hinnangud kogenud õpetajate õpetamistegevuste kvaliteedile olid alati kõrgemad algajate õpetajate õpetamistegevusele antavatest hinnangutest.
\end{abstract}

Võtmesõnad: õpilashinnangud, õpetaja tegevusviisid, õpetaja professionaalsus, algajad õpetajad, kogenud õpetajad

\section{Sissejuhatus}

Juba alates 1920. aastatest on pedagoogikateadlased ilmutanud jätkuvalt huvi kasutada õpetajate töö efektiivsuse hindamiseks õpilashinnanguid (Anderson \& Walberg, 1974; Doll, Spies, LeClair, Kurien, \& Foley, 2010;

1 Haridusteaduste instituut, Tartu Ülikool, Salme 1a, 50103 Tartu; anneokas@ut.ee 
Dowell \& Neal, 1982; Fauth, Decristan, Rieser, Klieme, \& Büttner, 2014; Hudelson, 1951; Kember \& Leung, 2011; Marsh \& Roche, 1997; McKeachie, 1997; McKeachie, Lin, \& Mann, 1971; Remmers, 1934; Rezler, 1965; Stehle, Spinath, \& Kadmon, 2012; Way, Reddy, \& Rhodes, 2007). Nii näiteks tuntakse huvi, millised on õpilaste hinnangud klassi motiveerimisele, õpilaste kaasamisele, tunni struktuuri kujundamisele ja laiemalt klassi juhtimisele õpetaja poolt (Wagner, Göllner, Helmke, Trautwein, \& Lüdtke, 2013).

Teadlased on diskuteerinud, kas õpilaste hinnangutele (students' perceptions) tuginemine õpetaja tegevuse uurimisel annab ikka objektiivse pildi õpetaja käitumisest ja loodud õpikeskkonnast. Küsimus seisneb selles, kas selline lähenemisviis on õpetaja ja õpikeskkonna uurimiseks sobiv (Clayson, 2009; Fauth et al., 2014; Fraser, 1989; Kunter \& Baumert, 2006; Scriven, 1988). Õpilashinnangute kasutamisel on viidatud metodoloogilistele raskustele (Lüdtke, Robitzsch, Trautwein, \& Kunter, 2009; Wagner et al., 2013). Kui üliõpilaste tagasisidet ainekursustele peetakse väga loomulikuks hindamisvahendiks kõrghariduses (Marsh, 2007; Spooren, Brockx, \& Mortelmans, 2013), siis põhikooliõpilaste hinnanguid peetakse liiga subjektiivseteks, tingituna õpilaste personaalsetest eelistustest ja kallutatud suhtumisest õpetajasse (De Jong \& Westerhof, 2001; Kunter \& Baumert, 2006). Mõned uurijad on avaldanud arvamust, et vaid kolleegid ja eksperdid suudavad hindamisel arvestada selliste võimalike mõjuteguritega nagu klassi suurus, õpilaste sugu või nende vanus (Aleamoni, 1999; Aleamoni \& Yimer, 1973). Samal ajal väljendatakse arusaama, et kuigi õpilaste hinnangud õpetajatele ei pruugi kajastada õpetajate reaalset käitumist, peegeldavad need teatud subjektiivsuse astmega siiski vähem või rohkem tegelikkust (Krips, 2008, 2011). Treenitud vaatlejate kasutamine ei anna alati sugugi paremat tulemust kui õpilaste hinnangutele tuginemine, sest võõras vaatleja ei tunne (vaatluse suhteliselt lühikese aja tõttu) ega õpigi tundma klassiruumis toimuva suhtluse tausta. Ka ei käitu klassis viibivad ópilased ja õpetajad võõra juuresolekul alati tavapärasel viisil (Krips, 2011). Seetõttu on osa uurijaid seisukohal, et õpetamise kvaliteedi hindamisel arvestatakse õpilaste arusaamadega liiga vähe (Cothran, Kulinna, \& Garrahy, 2003). Nii soovitatakse kasutada peale teiste õpetaja hindamise meetodite ka õpilaste hinnanguid (Den Brok, Wubbels, Veldman, \& Van Tartwijk, 2009; Duffield, Allan, Turner, \& Morris, 2000; Fauth et al., 2014). Ka aitab informeeritus õpilaste hinnangutest ja konstruktiivne refleksioon nende üle õpetajal näha võimalusi oma töö täiustamiseks (Pham et al., 2012). 


\section{Õpetajad ja nende tegevus õpilaste hinnangute põhjal}

Õpetaja sobivus tööks õpilastega sõltub oluliselt sellest, kuivõrd ta on suuteline käituma vastavalt nende ootustele (Krull, 2000). Tänapäevast õppimis- ja õpetamisprotsessi käsitlust kirjeldatakse kui õppijale soodsa õpikeskkonna loomist, mis tähendab, et õpetaja lähtub õpilase vajadustest, soovidest ja huvidest (Byman \& Kansanen, 2008). Õpilastel on küllalt konkreetsed ootused, missugune peaks olema ideaalne õpetaja, ning need olenevad koolis saadud kogemustest ja kultuurilisest tagapõhjast (Krull, 2000). Näiteks Nashi $(1976,2012)$ uuringud ühes Šoti keskkoolis näitasid, et 12aastased õpilased pidasid headeks õpetajaid, kes hoiavad korda ja on pigem ranged kui leebed (kuid vajaduse korral karistavad), panevad õpilased tööle, selgitavad õppematerjali arusaadavalt ning on abivalmis, huvitavad, õiglased, järjekindlad, sõbralikud ja heatahtlikud, pakuvad vaheldust ega ole tüütud, ei soeta lemmiklapsi ega kiusa kedagi, räägivad vaikselt ning on hea huumorimeelega.

Tavaliselt on õpilaste esimeseks (alateadlikuks) probleemiks kokkupuutel uue õpetajaga, kuidas selgitada välja, kuivõrd õpetaja suudab korda hoida, kas ta saab naljast aru ning kas ta ka mõistab õpilasi. Coheni, Manioni ja Morrisoni (2010) hinnangul on viimane aspekt kõige huvipakkuvam, sest see peegeldab klassi kui ühtekuuluva grupi suhet õpetajaga ja suhtumist temasse. See on märguanne õpetajale, et õpilaste käitumine klassis sõltub klassi kui terviku suhtumisest temasse. Kokkuvõtvalt, õpilased soovivad näha õpetajat autoriteedina, kes suudab luua klassiruumis toimuvale õppetööle etteaimatava struktuuri, reageerib otsustavalt õpilaste lubamatu, sh otseselt ohtliku tegevuse korral ning suudab mõista nii üksikõpilasi kui ka klassi tervikuna (Krull, 2000). Õpilaste ja õpetajate vahelised positiivsed suhted, iseäranis õpilaste tajutud toetav ja hooliv suhtumine, mõjutavad õpilasi, sundides neid pingutama ja raskuste korral oppetajalt abi otsima (Huges, Wu, Kwok, Villarreal, \& Johnson, 2012; Katz, Kaplan, \& Gueta, 2010; Skaalvik \& Skaalvik, 2013; Wentzel, 1998). Emotsionaalne toetus on sama tähtis kui akadeemiline toetus (Bru, Stephens, \& Torsheim, 2002; Cothran et al., 2003).

Õpilaste kujutlus nende rollist õppetöös ja üldse akadeemilise töö mõttest oleneb klassis valitsevast õpikeskkonnast, mida kujundavad õpilastele antavate ülesannete ja õppekorralduse süsteem, kasutatav hindamissüsteem ning õppimise eest vastutuse jaotus klassis (Ames, 1992). Õpilased tajuvad üsna selgelt mikrokliimat, kus neid ei toetata ja kus nende rahulolu on vähene. Õpetaja julgustav hoiak õpilaste suhtes toetab õpilaste potentsiaali väljaarendamist (Kitsing, Täht, \& Kukemelk, 2015). Motivatsiooni, 
sooritust ja arenemist soodustab selline ümbrus, mis võimaldab inimesel rahuldada oma psühholoogilisi vajadusi kompetentsuse, seotuse ja autonoomia järele (Deci \& Ryan, 1985). Õpetajast oleneb paljuski see, kas õpilane tunnetab eneseteostust (Ryan \& Deci, 2000). Õpetaja professionaalsus peakski väljenduma selles, et ta kutsub oma õpilastes esile positiivsed hoiakud enda suhtes, see tähendab, et õpetajat tajutakse kui entusiastlikku, innustavat, motiveerivat ja toetavat persooni.

\section{Algajast kogenud õpetajaks}

Õpetajate professionaalse arengu kirjeldamiseks on loodud mitmeid mudeleid (Barone, Berliner, Blanchard, Casanova, \& McGowan, 1996; Berliner, 1986; Burden, 1980; Conway \& Clark, 2003; Fuller, 1969; McDonald, 1982; Pigge \& Marso, 1997; Swennen, Jörg, \& Korthagen, 2004; Watzke, 2007 jt). Paljudes neis kajastub kas otsesemalt või kaudsemalt õpetaja valmisolek tööks õpilaste ja terve klassiga. Fulleri (1969) järgi avaldub õpetaja professionaalne areng muutustena tema tajutud probleemides. Õpetajate küsitluse tulemuste põhjal tegi Fuller järelduse, et algajast professionaaliks kujunemisel läbivad õpetajad neli probleemide ringi: õpetamiseelsed probleemid, ellujäämisprobleemid, mure õpetamise kui oma töö üldise tõhususe pärast ja mure iga õpilase arengu tagamise pärast. Õpetajatööd alustades on algajate õpetajate põhiline mureküsimus, kuidas klassi kontrolli all hoida. Professionaalsuse suurenedes ning enesekindluse kasvades hakatakse peamisi probleeme nägema suutlikkuses õpetada ainet ja seejärel õpilase arengu tagamises (ibid.).

Berlineri $(1986,1994,2001)$ mudel käsitleb õpetajate professionaalset arengut pedagoogiliste otsuste täiustumisena, sealhulgas kajastub selles võime arvestada kontekstiga (kaasa arvatud suhted õpilastega), milles õpetamine toimub. Õpetaja professionaalses kujunemises on Berlineri järgi eristatavad viis järk-järgult täiuslikumat taset: uustulnuk, edukas algaja, kompetentne õpetaja, professionaalne õpetaja ja meisterõpetaja. Uustulnukat iseloomustab kontekstivaba reeglite järgimine. Seevastu meisterlikkuse saavutanud õpetaja toetub otsuste langetamisel suures osas automatismidele ja intuitsioonile, kui tegemist on traditsiooniliste õppesituatsioonidega, ning tänu sellele saab ta probleemide ilmnemisel pühenduda nende analüüsile enam kui algajad õpetajad (Berliner, 1994). Kõigil viiel arenguastmel saab õpetaja erinevusi kutseoskustes iseloomustada nelja joonena: kuidas õpetaja suudab jälgida klassis toimuvat; milline on tema pingeseisund õpetamisel; kuivõrd ta toetub isiklikule kogemusele sündmuste ettenägemisel ja kuivõrd tema tähelepanu on suunatud õpilaste õppimise toetamisele, 
mitte murele oma tegevuse pärast (Kagan, 1992). Viimane dimensioon osutab otseselt õpetaja ja õpilaste suhte kvaliteedile, mis tõenäoliselt ei jää märkamata ka õpilastele.

Goodi ja Brophy (1995) üldistuse kohaselt eristab oma ala professionaali algajast asjaolu, et professionaal suudab paremini ja operatiivsemalt klassifitseerida probleemsituatsioone või sündmusi. Burden (1980), kes lasi õpetajatel iseloomustada nende kutsearengu etappe, toob välja ellujäämis-, kohanemis- ja küpsusperioodi. McDonald (1982) iseloomustab õpetajate professionaalset arengut ülemineku, uurimise, leidlikkuse ja eksperimenteerimise ning professionaalse õpetamise astmetena. Eelnimetatud käsitlustest said kõige suurema tähelepanu osaliseks 1960. aastate lõpust pärit Fulleri uurimused (vt ka Fuller \& Bown, 1975), mis panid aluse õpetajate professionaalse arengu käsitlemisele nende probleemide ja kogemuste seosena ka hilisemates uurimustes (Burden, 1990; Conway \& Clark, 2003; Swennen et al., $2004 \mathrm{jt}$ ).

Paljud uurimused näitavad, et meisterlikkuse saavutamine õpetamisel nõuab ulatuslikku õpetamiskogemust (Berliner, 1994, 2001; Ericsson, 1996). Seejuures, nagu osutab Berliner (2001), osa õpetajaid oma arengus kogenud õpetaja tasemest kaugemale ei jõuagi. Õpetaja professionaalsuse sügavamaks mõistmiseks tuleb arvestada sellega, et kujunemine oma ala meistriks on pikaajaline protsess, mida iseloomustavad kvalitatiivsed muutused õpetamisoskustes (Krull et al., 2013). Meisterõpetaja identifitseerimist käsitleva kirjanduse põhjal on töökogemus seatud õpetajate valiku üheks esmaseks kriteeriumiks (Palmer, Stough, Burdenski, \& Gonzales, 2005).

\section{Eesmärk ja uurimisküsimused}

Uurimuse eesmärk on selgitada välja, millisena tajuvad õpilased õpetaja tegevust tunnis, sealhulgas millised on erinevused hinnangutes algajatele ja kogenud õpetajatele, ning kõrvutada õpilaste hinnanguid õpetajate endi kujutlustega õpetamisest. Toetudes ülal tutvustatud õpetaja professionaalse arengu teooriatele, on põhjust eeldada, et uuringus osalenud kahe õpetajate rühma vahel esinevad kvalitatiivsed erinevused. Seega püstitati järgmised uurimisküsimused.

1. Millised erinevused ilmnevad õpilaste hinnangul algajate ja kogenud õpetajate tegevuses?

2. Millised seosed ilmnevad õpilaste ja õpetajate hinnangute vahel õpetaja professionaalsuse tajumisel? 


\section{Meetod}

\section{Uuringu disain}

Praegune uuring on osa õpetaja professionaalset tegevust käsitlevast mahukamast uuringust, kus algajad ja kogenud õpetajad panid kokku oma professionaalse arengu mapi (portfoolio), mis sisaldas järgmisi komponente: õpetaja professionaalsuse kirjeldust essee vormis, valikut õpilastele antavatest ülesannetest, kahte intervjuusalvestist (tunnieelne intervjuu ja stimuleeritud meenutusel põhinev tunnijärgne intervjuu), ainetunni videolindistust, õpetaja reflekteerivat kirjutist oma tugevatest ja nõrkadest külgedest õpetajana ning õpilaste hinnanguid konkreetse aineõpetaja tegevusele lindistatud tunnis (kirjaliku küsimustiku alusel). Artikkel kajastab tulemusi, mis on saadud järgmiste portfoolio komponentide analüüsist:

1) ópilaste hinnangud aineõpetaja tegevusele tunnis (küsimustik);

2) oppetajate intervjuud;

3) õpetajate reflekteerivad kirjutised.

Kogu uuringu keskseks elemendiks oli katses osaleva õpetaja välja valitud õppetund. Enne tundi paluti õpetajal anda intervjuu tunni kavandamise kohta, sellele järgnes planeeritud tunni andmine koos salvestamisega ning õpilaste kirjalik küsitlemine õpetaja tunnitegevuse kohta. Seejärel andis õpetaja stimuleeritud meenutuse meetodil intervjuu konkreetse tunni kohta ja lõpuks esitas ta reflekteeriva kirjutise, kus ta käsitles oma professionaalsust. Selline viieetapiline käsitlusviis võimaldas analüüsida õpetaja tegevust tunnis. Vastates küsimustikule (Van der Schaaf, 2005), väljendasid õpilased oma arvamust (taju, arusaama, ettekujutust) õpetaja tegevuse ja suhtumise kohta õpetamise seisukohalt olulistes aspektides.

Erinevate meetodite kasutamist inimkäitumist puudutavate andmete kogumisel nimetatakse kasvatusteaduslike uuringute kontekstis triangulatsiooniks (Cohen, Manion, \& Morrison, 2001). Siinses uuringus on triangulatsiooni kasutatud selleks, et kõrvutada õpilaste arusaamu õpetajate endi kujutlusega oma õpetamistegevusest.

\section{Valimi iseloomustus}

Uuringus osalesid kahe õppeaasta jooksul (2010/2011 ja 2011/2012) kümme algajat ja kümme kogenud Eesti põhikooliõpetajat (neist 18 nais- ja 2 meesõpetajat) ning nende õpilased ( $n=314$, vanus $12-16$ aastat). Kogenuteks loeti õpetajad, kes olid koolis töötanud vähemalt kümme aastat (vt Palmer et al., 2005). Enamik uuringus osalenutest oli töötanud õpetajana üle 25 aasta, staažikaim neist oli 44aastase töökogemusega. Algajad õpetajad olid oma õpetajakarjääri alguses (alla 3aastase töökogemusega). Uuringus 
osalenud õpetajad õpetasid põhikooli II ja III astmes eri aineid: eesti keelt emakeelena, inglise keelt võõrkeelena, matemaatikat, keemiat, bioloogiat, geograafiat ja ajalugu. Igalt uuringus osalenud ópetajalt lindistati üks 45minutiline ainetund. Õpetaja võis selle tunni ise valida. Õpilasrühmad moodustusid uuringus osalevate õpetajate tunnivaliku alusel. Videoaparatuur paiknes klassiruumis tagaseina ääres, kust oli võimalik õpetaja tegevust hästi jälgida.

\section{Mõõtevahendid ja andmekogumine}

\section{Tunnieelne intervjuu}

Intervjuu küsimused sõnastati NBPTSi valiidsusuuringu eeskujul (Bond, Smith, Baker, \& Hattie, 2000). Enne uuringuks valitud ainetunni salvestamist paluti õpetajatel vastata viiele selle tunni planeerimisega seotud küsimusele:

1. Mis on Teie tunni teema?

2. Mis on Teie tunni eesmärk?

3. Kui kaua aega võttis selle tunni ettevalmistamine? Kas see võttis rohkem või vähem aega kui tavaliselt?

4. Millele Te tavaliselt mõtlete tundi ette valmistades?

5. Milliste raskustega puutusite tundi ette valmistades kokku?

Uuringus osalenud õpetajate tunniplaneerimise, sealhulgas tunnieesmärkide püstituse kohta saab huvitatud lugeja lisainformatsiooni artiklist „Novice and experienced teachers' personal practical knowledge in planning lessons" (Okas, Van der Schaaf, \& Krull, 2013a).

\section{Küsimustik õpilaste hinnangute väljaselgitamiseks}

Et selgitada välja õpilaste hinnangud õpetamisele, kohandati Hollandis kasutatud samaotstarbelist küsimustikku (Van der Schaaf, 2005) Eesti olude tarbeks. Küsimuste arusaadavuses veendumiseks paluti 38 õpilasel sellele katseliselt vastata enne rakendamist põhiuuringus. Küsimustikus hindasid õpilased õpetaja tegevust neljapallisel Likerti skaalal, vastates 15 väitele (vt lisa 1).

Õpilased täitsid paberil küsimustiku vahetult peale uuringu otstarbel lindistatud õppetundi. Küsimustiku täitmise ajaks oli õpetaja klassist väljunud ning õpilased said juhised uurijalt. Õpilastele rõhutati, et küsimustikku täites annavad nad hinnangu sellele konkreetsele, just õpetaja antud tunnile. Peale küsimustiku täitmise juhiste jagati õpilastele ka selgitusi, kui mõni küsimus osutus neile arusaamatuks. Näiteks selgitati küsimuse 2 puhul, et konkreetses uuringus tähendavad rahuldavad töötingimused 
tavapäraselt õppimiseks sobivaid olusid. Küsimustiku täitmine võttis aega 10-15 minutit. Õpilaste küsimustiku sisemine reliaablus osutus väga heaks (Cronbachi $\alpha=0,92$ ). Originaalküsimustiku reliaablus Hollandi koolikontekstis rakendatuna oli hea (Cronbachi $\alpha=0,81$ ).

\section{Tunnijärgne intervjuu stimuleeritud meenutuse meetodil}

Peale lindistatud tundi tehti õpetajaga intervjuu stimuleeritud meenutuse meetodil. Enne tunnilindistuse vaatamist tutvustati õpetajale stimuleeritud meenutuse meetodi olemust ning julgustati teda igakülgselt oma mõtteid konkreetse tunni kohta avaldama. Kui uurija veendus, et õpetaja mõistis protseduuri olemust, siis alustati tunnivideo ülevaatamist. Vaatamise käigus seisati video kohe, kui õpetaja hakkas kommenteerima tunnis toimunut. Stimuleeritud meenutuse käigus andsid õpetajad oma kommentaarid ja üldistatult hinnangu tunni kordamineku kohta (vt täpsemalt Okas, Van der Schaaf, \& Krull, 2013b).

\section{Õpetajate reflekteerivad kirjutised}

Õpetajad esitasid uurijale kuu aja jooksul vabas vormis reflekteerivad kirjutised, kus nad avaldasid arvamust õpetaja professionaalsuse kohta ning tõid esile iseenda tugevad ja nõrgad küljed, probleemsed aspektid õpetajana (Okas, Van der Schaaf, \& Krull, 2014).

\section{Uurimiseetika}

Uurimistöö läbiviimisel pidasime väga oluliseks pedagoogilise uurimistöö eetikanormide järgimist. Osavõtt uuringutest oli vabatahtlik ja osalenutele tagati konfidentsiaalsus. Koostöös koolide juhtkondadega teavitati e-kooli kaudu kõigi uuringus osalevate klasside lapsevanemaid sellest, et nende laste õpetajad osalevad uurimistöös ning sellel otstarbel mõned ainetunnid lindistatakse. Ühtlasi paluti kõigi vanemate nõusolekut nende laste küsitlemiseks peale videosalvestatud tundi. Kui lapsevanem ei nõustunud lapse osalemisega uuringus, paluti lapsevanematel kontakteeruda uurijaga (artikli esimene autor) või kooli juhtkonnaga. Ükski 314 õpilase vanematest ei vaidlustanud osalemist. Uuringu lõppedes said õpetajad õpilaste tagasisidest kokkuvõtte, mille võis lisada oma professionaalse arengu mappi. Materjal ei sisaldanud ühegi õpilase personaalseid hinnanguid. Uurimistulemusi kajastavate artiklite näidetes on ópilaste nimed muudetud. Eetikanormidest kinnipidamisel lähtuti põhiliselt Briti hariduse teadusliku uurimise eetika koodeksist (BERA, 2011). 


\section{Andmetöötlus}

Andmetöötluse järjestus uuringus oli vastupidine andmekogumisele, kus töö algas tunnieelse intervjuuga ning lõppes õpilaste küsitluse ja õpetajate reflekteerivate kirjutistega. Andmeid töödeldes alustati õpilaste küsitlustulemuste analüüsist. Õpilaste küsimustiku sisemine reliaablus osutus väga heaks (Cronbachi $\alpha=0,92)$. Õpilashinnangute keskmiste erinevuste võrdluseks kasutati Studenti $t$-testi sõltumatutele rühmadele. Õpilaste küsitlustulemuste kõrvutamiseks intervjuudest ja reflekteerivatest kirjutistest kogutud mõtteavaldustega tehti uuriv faktoranalüüs, mille käigus grupeeriti omavahel seostuvad muutujad.

Faktoranalüüs andis ühefaktorilise lahenduse ja hõlmas muutujatena vastuseid kõigile küsimustiku väidetele. Kuivõrd faktoranalüüs ei pakkunud võimalusi muutujate grupeerimiseks, siis võeti tunnieelsetes intervjuudes, stimuleeritud meenutuse meetodil tehtud intervjuudes ja reflekteerivates kirjutistes kajastuvate ideede kategoriseerimise aluseks küsimustiku väited. Intervjuude ja reflekteerivate kirjutiste kvalitatiivse kontentanalüüsi tarbeks intervjuude audiosalvestised transkribeeriti. Tunnieelse intervjueerimise ja stimuleeritud meenutusega intervjueerimise tulemused on avaldatud eraldi artiklitena (Okas et al., 2013a, 2013b). Õpetajate reflekteerivates kirjutistes kajastuvate ideede põhjalikum analüüs on avaldatud eraldi kolmandas artiklis (vt lisaks Okas et al., 2014).

Uurimistulemuste usaldusväärsuse suurendamiseks rakendati kogutud andmete triangulatsiooni, kõrvutades õpilaste hinnanguid õpetajate reflekteerivates kirjutistes esitatud seisukohtadega ning intervjuudes väljatooduga. Kvalitatiivsele kontentanalüüsile lisaks kasutati tulemuste kõrvutamisel piiratult kvantitatiivset analüüsi, loendades õpetajate konkreetsetesse kategooriatesse koondunud mõtteavaldusi. Üksteisega sarnased väited/ kategooriad koondati ühise nimetaja alla (vt joonis 1).

\section{Tulemused}

\section{Õpilaste hinnangud algajatele ja kogenud õpetajatele kõrvutatuna ópetajate endi kommentaaridega tunnitegevuse kohta}

Õpilaste küsitlustulemuste keskmiste võrdlusest ( $t$-test) selgus, et kogenud õpetajate tegevusele antud hinnangud olid alati kõrgemad algajatele õpetajatele antud hinnangutest. T-testi tulemustest annab ülevaate tabel 1 . 
Tabel 1. $T$-testi ja kirjeldava statistilise analüüsi tulemused $(n=314, d f=312)$

\begin{tabular}{|c|c|c|c|c|}
\hline \multirow[t]{2}{*}{ Kategooriad/küsimused } & \multicolumn{2}{|c|}{$M$} & \multirow{2}{*}{$\begin{array}{l}t \text {-väär- } \\
\text { tus }\end{array}$} & \multirow{2}{*}{$\begin{array}{l}\text { Efekti } \\
\text { suurus }\end{array}$} \\
\hline & $\begin{array}{l}\text { Algajad } \\
\text { õpetajad }\end{array}$ & $\begin{array}{l}\text { Kogenud } \\
\text { õpetajad }\end{array}$ & & \\
\hline 1. Tunni eesmärk on selge & 2,41 & 3,32 & $10,69^{*}$ & 0,52 \\
\hline 2. Meil on rahuldavad tingimused töö tegemiseks & 3,06 & 3,42 & $5,86^{*}$ & 0,31 \\
\hline 3. Tunni ülesannete sisu on selge & 2,60 & 3,54 & $12,70^{*}$ & 0,58 \\
\hline 4. Tunni ülesanded on rasked & 2,08 & 2,58 & $5,50^{*}$ & 0,30 \\
\hline 5. Õpetaja annab praktilisi juhiseid & 2,16 & 3,21 & $14,10^{*}$ & 0,62 \\
\hline $\begin{array}{l}\text { 6. Õpetaja kontrollib regulaarselt, kas me saame } \\
\text { ülesandest aru }\end{array}$ & 2,14 & 3,24 & $12,41^{*}$ & 0,57 \\
\hline 7. Õpetaja annab selgeid juhiseid & 2,07 & 3,50 & $18,60^{*}$ & 0,73 \\
\hline 8. Õpetaja on entusiastlik & 1,95 & 3,06 & $11,76^{*}$ & 0,55 \\
\hline 9. Õpetaja on valmis selgitama mitu korda & 2,43 & 3,46 & $12,89^{*}$ & 0,59 \\
\hline 10. Õpetajal on meisse usku & 2,47 & 3,25 & $10,20^{*}$ & 0,50 \\
\hline 11. Õpetajal on suured ootused & 2,56 & 3,54 & $10,45^{*}$ & 0,51 \\
\hline 12. Õpetaja on meist huvitatud & 1,94 & 2,94 & $10,34^{*}$ & 0,50 \\
\hline 13. Õpetaja näitab üles huvi meie ideede vastu & 1,70 & 2,44 & $7,53^{*}$ & 0,40 \\
\hline $\begin{array}{l}\text { 14. Õpetaja paneb tähele ja toetab } \\
\text { õpilastevahelist suhtlemist }\end{array}$ & 2,74 & 3,29 & $7,07^{*}$ & 0,37 \\
\hline $\begin{array}{l}\text { 15. Õpetaja kontrollib, kas me tegelikult } \\
\text { töötame tunni ülesannete kallal }\end{array}$ & 3,40 & 3,72 & $4,92^{*}$ & 0,27 \\
\hline
\end{tabular}

Märkus. * $-p<0,05$.

Järgnevalt on igale õpilasküsimustiku väitele antud vastuseid detailsemalt kirjeldatud (näidetes $\mathrm{A}=$ algajad õpetajad; $\mathrm{K}=$ kogenud õpetajad; $\mathrm{I}=$ tunnieelne intervjuu; $\mathrm{S}$ = intervjuu stimuleeritud meenutuse meetodil; $\mathrm{R}=$ reflekteeriv kirjutis).

\section{Tunni eesmärk on selge}

Õpilaste hinnangul püstitasid kogenud õpetajad selgemad tunnieesmärgid $(t=10,69 ; p<0,05)$. Kuivõrd tunnieelse intervjuu ajal esitati küsimus tunnieesmärkide kohta (Okas et al., 2013a), siis ka tunnijärgne intervjuu stimuleeritud meenutuse meetodil hõlmas eesmärkidega seotud kommentaare. 
Õpetajate mõtteavaldusi tunnieesmärkide kohta oli kokku 28. Enamasti sisaldasid need algajate õpetajate puhul üldsõnalisi hinnanguid eesmärkide saavutamise kohta.

Me võtsime tänaseks planeeritu kenasti läbi. (A, S)

Kogenud õpetajate kommentaarid väljendasid paindlikkust. Õpetajad reageerisid kiiresti tunnis toimuvale ja möönsid, et muutsid vajaduse korral oma algset tegevusplaani.

Tunni esimene pool läks mul nii, nagu planeerisin, aga siis ma muutsin ja teises osas ma uue osa tutvustamisest loobusin, sest uue osa juurde minekuks vajasid nad rohkem aega. $(\mathrm{K}, \mathrm{S})$

\section{Meil on rahuldavad tingimused töö tegemiseks}

Õpilased tajusid kogenud õpetajate tundide töötingimusi parematena $(t=5,86 ; p<0,05)$. Üks tegureid, miks õpilastel kujunes selline arusaam, võib olla tunni töökorra-distsipliini tagamine. Kogenud õpetajad pidasid distsipliini hoidmist enda tugevuseks. Nad rõhutasid reflekteerivates kirjutistes ja intervjuudes distsipliini tähtsust ning õpetaja rolli korra tagamisel. Seevastu algajad õpetajad võtsid omaks, et neil on probleeme, ja pidasid seda oma nõrgaks küljeks.

Õpetan teist aastat, kogu esimene aasta läks distsipliini peale, põhirõhk oli sellel. (A, R)

Tunnis korda ikka veel ei ole. Täna olid nad suhteliselt rahulikud. (A, S)

Teine tegur, miks õpilased hindasid kogenud õpetajaid kõrgemalt, võib olla metoodiliste võtete süsteemne kasutamine õpetamisel. Kogenud õpetajad rõhutasid mitmekesiste metoodiliste võtete vajalikkust, õpilaste aktiveerimist ja rühmatöö võimaluste kasutamist. Intervjuude ja reflekteerivate kirjutiste analüüs näitas, et noored õpetajad nägid häid väljavaateid IKT-vahendite kasutamises ning digiõppe rakendamises, samas nende eakamad kolleegid leidsid, et üha laienev e-süsteem ei lahenda kõiki õppimise ja õpetamisega seotud probleeme. Algajatelt õpetajatelt oli rohkelt mõtteavaldusi kasutatud IKT-vahendite ja -võtete kohta, seevastu kogenud õpetajad pöörasid sellele aspektile vähem tähelepanu.

Laen oma materjali üles ka internetti. (A, R)

E-õpe on küllaltki väikese kasuteguriga. (K, R) 


\section{Tunni ülesannete sisu on selge}

Kogenud õpetajad pakkusid õpilaste arvates selgema sisuga ülesandeid $(t=12,70 ; p<0,05)$. Õpetajate reflekteerivates kirjutistes ja tunnikommentaarides oli arvukalt osutusi õpilastele antud ülesannete kohta (kogenud õpetajatelt sellekohaseid mõtteavaldusi 44 , algajatelt 18).

See ülesanne valmistas ette järgmise lahendamist, need ülesanded koostan tavaliselt kahes raskusastmes. (K, S)

Selle ülesandega kinnistasid nad algoritmi rakendamisoskust. (K, S)

Minu meelest on selle osa läbimisel oluline, et meil oleks aega lahendada võimalikult eritüübilisi ülesandeid, mille läbi võib loota mõtestatud seoste teket. (K, S)

Teema on õpikus esitatuna õpilastele pisut raske mõista, nii et mina esitan seda lihtsamalt ja arusaadavamalt. (K, I)

Selle osa kohta on õpikus päris palju harjutusi. (A, I)

\section{Tunni ülesanded on rasked}

Uuringus osalenud õpilaste hinnangul pakkusid kogenud õpetajad välja raskemaid tunniülesandeid $(t=5,50 ; p<0,05)$. Õpetajate kommentaarides kajastus korduvalt püüd õppetegevust diferentseerida ning kasutada õpilaste tasemele vastavaid, võimetekohaseid ülesandeid. Selliseid osutusi oli kogenud õpetajatelt 21, algajatelt 8.

Osa õpilastest lahendab mul alati suurema raskusastmega ülesandeid, mis on ühtlasi ettevalmistus aineolümpiaadile minekuks. (K, S)

Olen püüdnud järk-järgult tõsta lahendatavate ülesannete mahtu ja seda diferentseerida. $(\mathrm{K}, \mathrm{S})$

On õpilasi, kellele polegi õpikus nagu võimetekohaseid ülesandeid. (A, S)

\section{Õpetaja annab praktilisi juhiseid; ópetaja annab selgeid juhiseid}

Õpilaste hinnangul andsid kogenud õpetajad tunnis enam praktilisi juhiseid $(t=14,10 ; p<0,05)$ ning selgeid tööjuhiseid $(t=18,60 ; p<0,05)$. Oppetajate kommentaaride sarnasuse ja läbipõimumise tõttu vaatleme nende kahe küsimuse puhul tulemusi koos. Juhendamise ja juhiste andmisega seotud kommentaare oli kogenud õpetajatelt 46, algajatelt 21. Kogenud õpetajad rõhutasid tööjuhiste (juhendite) tähtsust ja töö korraldamise olulisust, 
algajate kommentaarides domineeris õpilaste vähene suutlikkus ülesandeid iseseisvalt tulemuslikult lahendada, mis kinnitab õpilaste tajutut.

Selles klassis on vajalik tööjuhendite eelnev ühine arutelu. (K, S)

Algajate vastustest tuli selgelt esile õpilaste vähene võimekus.

Mind häirib see, et tunnist tundi on üks osa õpilasi, kes ei saa tööjuhendist aru. (A, S)

Paljudel õpilastel puuduvad iseseisva töö oskused. (A, R)

Õpetaja kontrollib regulaarselt, kas me saame ülesandest aru; ópetaja kontrollib, kas me tegelikult töötame tunni ülesande kallal

Kogenud õpetajate tundides tajusid õpilased selgemalt, et kontrollitakse, kas nad ikka saavad tunni ülesannetest aru $(t=12,41 ; p<0,05)$. Niisamuti leidsid õpilased, et kogenud õpetajad kontrollivad algajatest enam ka seda, kas õpilased tegelikult töötavad tunni ülesannete kallal $(t=4,92 ; p<0,05)$.

Kogenud õpetajatelt oli intervjuudes ja reflekteerivates kirjutistes õpilaste kontrollimisega seotud mõttearendusi 39, algajatelt 31. Intervjuudest ja reflekteerivatest kirjutistest ilmnes, et ka algajad õpetajad on üksjagu kontrollivad. Järgnevalt on esitatud mõned näited uuringus osalenud õpetajate kirjutistes ja tunnikommentaarides leiduvate mõtete kohta.

Õpilaste töötulemuste kontrollimine tunnis peab seostuma kohese tagasisidega õpilasele. $(\mathrm{K}, \mathrm{S})$

Õpilasi tuleb õpetada ise oma töö tulemust kontrollima. (K, S)

Keerulisemate ülesannete korral on oluline tagada õpilastele ka vahetulemuste kontroll. (K, S)

Ülesande lahendamiseks on vaja anda aega, alles siis on põhjust asuda tehtut kontrollima. (A, S)

Tunni piiratud aeg ei võimalda sageli tunnis tehtut kontrollida ja õpilastele tagasisidet anda. (A, R)

Kontrollin, et õpilased ei tegeleks tunnis kõrvaliste asjadega. (A, R)

\section{Õpetaja on entusiastlik}

Õpilaste hinnangul olid kogenud õpetajad entusiastlikumad ( $t=11,76$; $p<0,05)$. Õpetajate reflekteerivates kirjutistes on küll märgitud, et „õpetaja 
peab olema avatud" ja "positiivse ellusuhtumisega”, kuid otseselt entusiasmi ei mainitud.

\section{Õpetaja on valmis selgitama mitu korda}

Õpilaste arvates olid kogenud õpetajad enam valmis korduvalt selgitusi jagama $(t=12,89 ; p<0,05)$. Opetajate kommentaarides ja kirjutistes oli sellele aspektile osutavaid mõtteavaldusi kogenutelt 14 , algajatelt 6 . Õpetajad arutlesid peamiselt järgmiste teemade üle: eeltöö vajadus, et säästa aega, mitte kulutada seda korduvateks selgitusteks; korduv selgitamine kaaslastest nõrgematele õpilastele; korduv selgitamine juhtudel, kui õpilane ise pöördub küsimusega õpetaja poole; keeldumine korduvast selgitamisest õpilasele, kes segas tundi jms.

Õpetaja peab olema rahulik, pika ja kannatliku meelega. (K, R)

Ei jää aega pikemaks selgitamiseks. (A, R)

Ainekava maht on suur ja seetõttu napib aega nõrgematele selgitada. $(\mathrm{A}, \mathrm{R})$

\section{Õpetajal on meisse usku; õpetajal on suured ootused; ópetaja on meist huvitatud; ópetaja näitab üles huvi meie ideede vastu}

Need õpilasküsimustiku väited on kaudselt seotud õpilaste motiveerimise ja õpilastest hoolimise või õpilaskesksusega. Tulemused näitavad, et nendegi väidete puhul olid hinnangud kogenud õpetajatele kõrgemad kui nende algajatele kolleegidele. Õpilaste hinnangul olid kogenud õpetajad õpilaste suhtes suuremate ootustega $(t=10,45 ; p<0,05)$, näidates üles suuremat huvi õpilaste $(t=10,34 ; p<0,05)$ ja nende ideede vastu $(t=7,53$; $p<0,05)$ ning uskudes algajatest enam oma õpilaste võimetesse $(t=10,20$; $p<0,05)$. Usku ja suuri ootusi, aga ka mõneti vastupidist väljendasid õpetajad järgmiste mõtteavaldustena (kogenutelt 15, algajatelt 8).

Oluline on õpilastele sisendada usku oma võimetesse. (A, R)

Enamus mu õpilastest on võimekad. (K, S)

Paljudele on suuline kiitus tunnustuseks, mis paneb nad ka järgnevalt pingutama. $(\mathrm{K}, \mathrm{S})$

Suurele osale õpilastest on vastumeelne igasugune pingutus, nii vaimne kui kehaline. $(\mathrm{A}, \mathrm{R})$ 
Paljudel on võimeid enamaks, kuid puuduvad elementaarsedki tööoskused, tahtmine. (K, R)

Tahetakse tunnustust, aga pingutada ei viitsita. (A, R)

Õpilaskesksusele (õpilasküsimustiku väited ópetaja on meist huvitatud ja ópetaja näitab üles huvi meie ideede vastu) osutavad õpetajate kommentaarid, mis väljendavad hoolivat suhtumist õpilastesse ning arvestamist õpilaste mõtete ja initsiatiiviga.

Tuuli on haiguse tõttu pikemalt puudunud, muidu on ta oivik, aga just nende puudumiste tõttu oli ta täna tunnis nõrgem. $(\mathrm{K}, \mathrm{S})$

Tal on väga keeruline kodune olukord. (A, S)

Mõnel juhul mu õpilased ise valivad arutlusteemasid. (A, I)

Olen koduses lühikirjandis kasutanud erinevat lähenemist. Ühel juhul annan teemad, mille seast nad ise valivad. Teisel juhul kirjutavad ise vabal teemal. $(\mathrm{K}, \mathrm{I})$

\section{Õpetaja paneb tähele ja toetab õpilastevahelist suhtlemist}

Õpilaste hinnangul olid kogenud õpetajad tähelepanelikumad, toetades õpilaste suhtlemist üksteisega $(t=7,07 ; p<0,05)$. Õpetajate kommentaarides videosalvestatud tundidele oli ópilaste suhtluse ja selle suunamisega tunnis seotud osutusi kogenud õpetajatelt pea kaks korda rohkem (38) kui algajatelt (20). Veelgi enam erines nende mõtteavalduste sisu: algajate õpetajate repliigid tunnis toimunu kohta keskendusid distsipliinile.

Ma ei luba mingit kõrvalist tegevust. (A, S)

Korrarikkujaga vestlen kohe peale tundi vahetunnis. (A, S)

Kogenud õpetajate kommentaarid sisaldasid arutlusi rakendatud metoodiliste võtete kasutamise kohta.

Rühmatööks kasutan erinevaid mooduseid, kord moodustub rühm ópilaste endi valikul, teine kord jagan mina nad näiteks kolme, erineva võimekustasemega rühma. $(\mathrm{K}, \mathrm{S})$

Kogenud õpetajatelt pärineb kuus repliiki, mis on seotud distsipliiniga tunnis. Nende mõtete rõhuasetus oli algajate omast aga hoopis erinev. 
Nii leiavad endale sobiva rakenduse ka muidu tööst kõrvalekalduvad. $(\mathrm{K}, \mathrm{S})$

Mõne potentsiaalse korrarikkuja töölepanekuks on see [küsimuste koostamine ja kaaslastele esitamine] väga hea võte. (K, S)

Algajate ja kogenud õpetajate mõtteavaldusi analüüsides kasutati piiratult ka kvantitatiivset analüüsi ning loendati õpetajate konkreetsetesse kategooriatesse koondunud mõtteavaldusi arvuliselt (vt joonis 1).

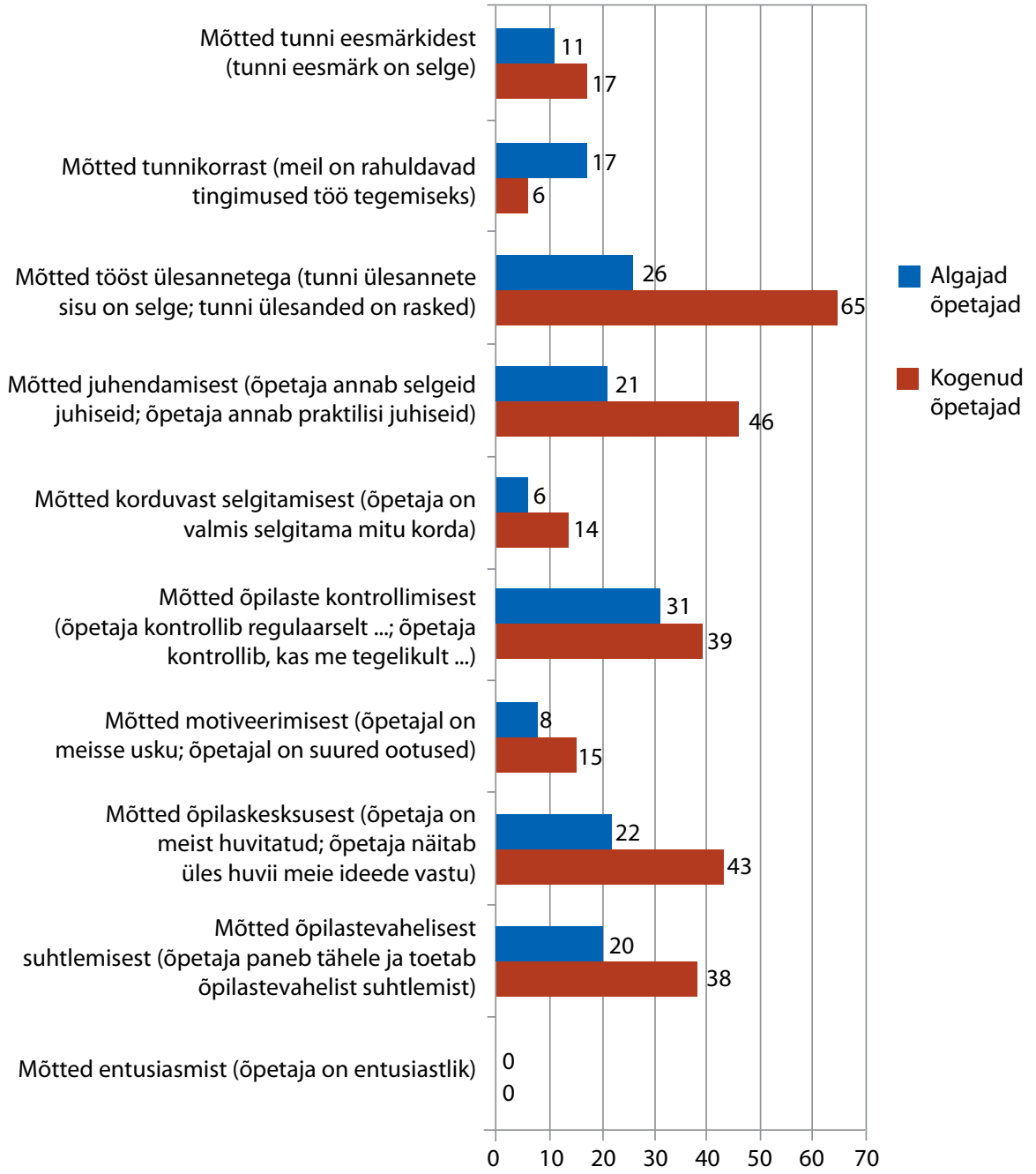

Joonis 1. Algajate ja kogenud õpetajate mõtteavaldused intervjuudes ja reflekteerivates kirjutistes 
Õpetajate intervjuudes ja reflekteerivates kirjutistes kommenteeriti kõige enam tunni ülesannetega seonduvat (91) ning kordagi ei kasutatud terminit entusiasm (0). Kogenud õpetajad esitasid arvuliselt enam mõtteid võrreldes algajate õpetajatega pea kõikides kategooriates. Algajatelt õpetajatelt oli enam mõtteid vaid tunnikorra kohta. Algajate ja kogenud õpetajate mõtteavaldused ning kommentaarid erinesid nii arvuliselt kui ka sisuliselt.

\section{Arutelu}

Uurimuse eesmärk on selgitada välja, millisena tajuvad õpilased õpetaja tegevust tunnis, sealhulgas millised on erinevused hinnangutes algajatele ja kogenud õpetajatele, ning võrrelda õpilaste hinnanguid õpetajate endi kujutlustega õpetamisest. Uurimistulemused näitavad, et õpilased tajuvad suurema kogemusega õpetajate õpetamistegevusi tõhusamana kui algajate õpetajate omi. Seejuures ilmneb, et õpilaste tajutu langeb suuresti kokku sellega, mida õpetajad ise on nii õppetunnile eelnevates ja järgnevates intervjuudes kui ka reflekteerivates kirjutistes öelnud. Uurimusest selgub, et õpilased hindavad kogenud õpetajate õpetamistegevusi kõrgemalt kõigi õpilasküsimustikus esitatud väidete puhul.

Õpilased tajusid suurema töökogemusega õpetajate tundides loodud töötingimusi parematena. Üks põhjuseid võis olla õpetajapoolne töökorradistsipliini tagamine. On tavaline, et õpetajatööd alustades on noorte õpetajate põhiline mureküsimus, kuidas suurt klassi kontrolli all hoida (Eraut, 1994; Fuller, 1969). Algajad õpetajad võivad küll teoretiseerida tunnikorra loomise üle, kuid samal ajal on nad sellega ise hädas (Eraut, 1994). Kogenud õpetajate osutused tunni töökorrale olid hoopis teises võtmes kui algajatel. Nad märkisid, et töökorra tagamine on nende üks tugevaid külgi ning see pole nende jaoks probleem. Algajad seevastu tunnistasid oma probleeme tunni distsipliiniga. Õpilaste kõrgemat positiivset hinnangut kogenud õpetajatele võis mõjutada ka õpetajate kasutatavate metoodiliste võtete süsteemsus. Kogenud õpetajad rõhutasid vajadust kasutada mitmekesiseid metoodilisi võtteid ning stimuleerida õpilaste aktiivsust.

Õpilased soovivad teada, mille õppimist neilt oodatakse ja mida nad peaksid suutma õppimise tulemusena teha. Seetõttu peaks õppimise oodatava tulemuse sõnastus olema õpilastele hästi arusaadav (Gagne \& Driscoll, 1992). Kõnealuses uuringus tajusid õpilased kogenud õpetajate puhul selgemalt tunni eesmärki. Niisamuti hindasid nad selgemaks kogenud õpetajate tundides antavate ülesannete sisu. Kõrvutades neid uurimistulemusi teiste autorite, näiteks Wangi, Haerteli ja Walbergi (1993) ning White’i (2009) omadega, saab nende vahele tõmmata mitmeid paralleele. 
Õpilasküsimustiku väited ópetaja annab praktilisi juhiseid ja õpetaja annab selgeid juhiseid seonduvad õpetajapoolse juhendamisega. Ôpilaste otsuste tegemisel võis saada määravaks, kui selgelt ja arusaadavalt õpetaja suutis tunnis tehtavate ülesannete sisu ja olemust õpilastele selgitada. Põhjust, miks kogenud õpetajad pälvisid kõrgemad hinnangud oma õpilastelt seoses valmidusega selgitada õppematerjali korduvalt, saab näha selles, et algajad õpetajad on sageli raskustes tunniks kavandatu teostamisega. Neile võib olla probleemiks õpetatava sisu edastamine, ajakasutus ja korra hoidmine klassis, nagu on näidanud varasemad uuringud (Arens, Morin, \& Watermann, 2015; Burden, 1980; Fuller, 1969; Huberman, 1992; Pigge \& Marso, 1997; Watzke, 2007).

Kuigi uuringus osalenud algajad õpetajad olid nende endi hinnangul samuti üksjagu kontrollivad, tajusid kogenud õpetajate õpilased, et nende õpetajad pööravad enam tähelepanu sellele, kas nad ka tegelikult teevad tunnis ülesandeid ning saavad nendest aru. Õpilase hinnang võib sõltuda töökorraldusest. Näiteks oleneb antavatest ülesannetest see, kas saab kasutada tööviise, mis võimaldavad anda tagasisidet ka õppetöö käigus, mitte ainult lõpus. On päris loomulik, et kogenud õpetajatel on mahukate, mitmetahuliste õppeülesannete korral algajate ees teatavad eelised, sest nad oskavad anda vahetulemuste kaudu õpilastele tagasisidet ja seeläbi kontrollida ülesandest arusaamist.

Üks olulisi suhtlusdimensioone, milles väljendub õpetaja käitumine, on hoolivus (Krips, 2011). Õpilase suhtumist ainesse ja selles toimetulekut, sh tema õpimotivatsiooni, mõjutab see, kuidas ta õpetaja hoolivust tajub (Wentzel, 1997). Eesti põhikooli- ja gümnaasiumiõpilastega tehtud uuring osutab selliste väärtuste nagu kaitstus, hoolivus, sallivus ja abistamine võimalikule defitsiidile Eesti koolis (Ruus et al., 2007). Praeguses uuringus osalenud õpilaste hinnangul väljendavad kogenud õpetajad enam hoolivust kui algajad. Õpilane tajub hoolivust suhtluses õpetajaga eri tegevuste kaudu. Näiteks kui õpetaja motiveerib õpilast oma tulemust parandama, siis see ongi kinnitus, et õpetajal on temasse usku. Niisamuti avaldub hoolivus selles, kui tavapärastest keerukamate ülesannete korral õpetaja julgustab õpilasi nende kallal tööd tegema. Deci ja Ryan (1985) rõhutavad, et toetatuna ja stimuleerituna jõutakse soovitud tulemuseni.

Kõnealuses uuringus osalenud õpetajate reflekteerivates kirjutistes oli kõige enam mõtteavaldusi õppimistingimuste loomise kohta ja kõige vähem õpilaskesksuse või hoolivuse kohta. Seetõttu on põhjust väita, et keskendudes õppimistingimuste loomisele ning selgele juhendamisele, väljendub selles ka hooliv suhtumine õpilastesse. 
Entusiasm on üks kõige sagedamini esiletoodavatest hea õpetaja karakteristikutest (Witcher, Onwuegbuzie, \& Minor, 2001). See on paljude autorite arvates kvaliteetse juhendamise võtmeküsimus (Brophy \& Good, 1996; Long \& Hoy, 2006; Witcher, et al., 2001). Entusiasmi aspekti õpetamistegevuses on põhjalikult uurinud Kunter oma kolleegidega. Uuringutest ilmneb, et need õpetajad, kes on õpetamistegevuses entusiastlikumad, paistavad nii enda hinnangul kui ka õpilaste arvates silma kvaliteetsema juhendamistegevuse poolest (Kunter, Frenzel, Nagy, Baumert, \& Pekrun, 2011; Kunter et al., 2008). Praeguses uuringus andsid õpilased väite õpetaja on entusiastlik korral kogenud õpetajatele eriti kõrgeid hinnanguid võrreldes algajatega. Algajate õpetajate puhul tunnetatud vähest entusiasmi võib õpetajate endi kirjutistele tuginedes seletada sellega, et nad on tunni andmisel seotud oluliste probleemidega, nagu ainesisu edastamine, ajakasutus ja distsipliini hoidmine klassiruumis.

Õpilasküsitluse tulemused kinnitasid õpetajate väljaöeldut. Algajad õpetajad väljendasid intervjuudes ja reflekteerivates kirjutistes oma mõningat ebakindlust. Uuringus osalenud õpilased andsid algajatele õpetajatele madalamaid hinnanguid, millest saab järeldada, et õpilased tajuvad noorte õpetajate endi sõnastatud muresid. McPherson (2006) ning McPherson, Todd Jewell ja Kim (2009) on uurinud õpilashinnanguid mõjutavaid tegureid ning toonud välja, et üks olulistest mõjuritest on õpetaja töökogemus: kogenud õpetajad saavad kõrgemaid hinnanguid.

Uuringus ilmnenu ja eriti see, mis puudutab kogenud õpetajatele antud kõrgemaid hinnanguid, viitavad ka võimalusele, et õpetajate valimisse on sattunud meisterõpetajad, kellel on suured kogemused ja ka õpetajatööks vajalikud isiksuseomadused. Seevastu algajad õpetajad olid vähese töökogemusega ning osalt sellised õpetajad, kes polnud veel kohanenud koolisituatsiooniga. Õpetajate valim on aga sedavõrd väike, et üldistuste tegemine oleks meelevaldne. Lisaks ei kontrollitud enne uuringut õpetajate professionaalsuse astet, nende vastavust kõigile meisterõpetaja kriteeriumitele. Nende professionaalsusele osutasid vaid haridus ja töökogemus.

Uuringul on mitmeid piiranguid. Kuna uuriti vaid kümnele algajale ja kümnele kogenud õpetajale antud hinnanguid, ei saa teha üldistusi õpetajaskonna kohta. Ka ei saa uuringus osalenud õpilaste valimit Eesti põhikooliõpilaste suhtes esinduslikuks pidada. Samuti ei saa öelda, et mitte ühegi algaja tunnis mitte ükski õpilane end hästi ei tundnud ja vastupidi. Valimi väiksus on tingitud sellest, et kõnealune uuring on osa mahukast, valdavalt kvalitatiivsest uuringust, kus vaatluse alla võeti kümne algaja ja kümne kogenud õpetaja praktiline teadmine. Lisaks, kuigi ópilastel paluti hinnata õpetaja tegevust just ühes konkreetses tunnis, pole välistatud, et 
õpilased tegid küsimustikule vastates üldistusi ning hindasid konkreetset õpetajat üldiselt.

\section{Kokkuvõte ja järeldused}

Uurimusest ilmneb, et algajatel õpetajatel jääb nii õpilaste kui ka nende endi hinnangul kogenud õpetajatega võrreldes puudu mitmetest oskustest. Tulemustes kajastub tõsiasi, et õpilased on algajate õpetajate tundides tajunud momente, mida needsamad õpetajad ka ise oma õpetamistegevust analüüsides enda nõrkadeks külgedeks pidasid.

Uuringust saadud teavet võib kasutada muudatuste tegemiseks õpetajakoolituses. Õpetajate valimi väiksusest hoolimata kinnitas uuring varasemaid tulemusi, mis osutavad erinevustele algajate ja kogenud õpetajate töös. Uurimistulemuste põhjal saab teha mitmeid ettepanekuid õpetajakoolituse teoreetilise ja praktilise poole parandamiseks. Näiteks võiks senisest enam pöörata tähelepanu üliõpilase enda antud tunni lindistuse analüüsile ja tunnis toimunu meenutamisele ning seeläbi keskenduda õpetamistegevusele ja selle täiustamisele. Hinnangute usaldusväärsuse tagamiseks võib tulemusi kõrvutada õpetaja enesehinnangutega ning kolleegide, sõltumatute vaatlejate/ekspertide ja õpilaste hinnangutega.

Töö autorid leiavad, et õpilashinnangute kasutamine õpetajatöö analüüsimisel on oluline meetod, enesestmõistetavalt mitte määrav. Õpilaste küsitlemine on aktsepteeritud ja igati sobilik meetod, mis võimaldab uurida õpetaja tegevust klassiruumis õpilaste vaatevinklist. Lisaks pakub eri hindamismeetodite kombineerimine - õpetajate intervjueerimine, reflekteeriv kirjutamine ning õpilaste küsitlemine - eelkõige algajale õpetajale võimalust süvendatud eneseanalüüsiks. Eraldi uurimist vajaks, mis aitaks algajatel õpetajatel saavutada kiiremini kogenud õpetajatele omast enesekindlust, et õpilased tunneksid nendega töötades end sama suunatult kui kogenud professionaali tundides.

\section{Tänuavaldus}

Artikli valmimist toetas Euroopa sotsiaalfond haridus- ja kasvatusteaduste doktorikooli kaudu (1.2.0401.09-0070). Täname artikli anonüümseid retsensente põhjaliku tagasiside ja asjalike nõuannete eest. Suurim tänu kuulub uuringus osalenud õpilastele ja õpetajatele. 


\section{Kasutatud kirjandus}

Aleamoni, L. M. (1999). Student rating myths versus research facts from 1924 to 1998. Journal of Personnel Evaluation in Education, 13(2), 153-166.

doi: http://dx.doi.org/10.1023/A:1008168421283

Aleamoni, L. M., \& Yimer, M. (1973). An investigation of the relationship between colleague rating, student rating, research productivity and academic rank in rating instructional effectiveness. Journal of Educational Psychology, 64(3), 274-277. doi: http://dx.doi.org/10.1037/h0034584

Ames, C. (1992). Classrooms: Goals, structures, and student motivation. Journal of Educational Psychology, 84(3), 261-271. doi: http://dx.doi.org/10.1037/0022-0663.84.3.261

Anderson, G. J., \& Walberg, H. J. (1974). Learning environments. In H. J. Walberg (Ed.), Evaluating educational performance: A sourcebook of methods, instruments and examples. Berkeley, CA: McCutchan.

Arens, A. K., Morin, A. J. S., \& Watermann, R. (2015). Relations between classroom disciplinary problems and student motivation: Achievement as a potential mediator? Learning and Instruction, 39, 184-193.

doi: http://dx.doi.org/10.1016/j.learninstruc.2015.07.001

Barone, T. E., Berliner, D. C., Blanchard, J., Casanova, U., \& McGowan, T. (1996). The future of teacher education. Developing a strong sense of professionalism. In J. Sikula (Ed.), Handbook of research on teacher education (2nd ed., pp. 11081149). New York: Simon \& Schuster.

BERA (2011). Ethical guidelines for educational research. London. Retrieved from https://www.bera.ac.uk/researchers-resources/publications/ethical-guidelinesfor-educational-research-2011.

Berliner, D. C. (1986). In pursuit of the expert pedagogue. Educational Researcher, 15(7), 5-13. doi: http://dx.doi.org/10.3102/0013189X015007007

Berliner, D. C. (1994). Expertise: The wonders of exemplary performances. In J. N. Mangieri \& C. Collins Block (Eds.), Creating powerful thinking in teachers and students (pp. 141-186). Ft. Worth, TX: Holt, Rinehart \& Winston.

Berliner, D. C. (2001). Learning about and learning from expert teachers. International Journal of Educational Research, 35(5), 463-482.

doi: http://dx.doi.org/10.1016/S0883-0355(02)00004-6

Bond, L., Smith, T. W., Baker, W. K., \& Hattie, J. A. (2000). The certification system of the National Board for Professional Teaching Standards: A construct and consequential validity study. Greensboro, NC: Center for Educational Research and Evaluation, University of North Carolina.

Brophy, J., \& Good, T. L. (1996). Teacher behaviour and student achievement. In M. Wittrock (Ed.), Handbook of research on teaching (pp. 340-370), New York: Macmillan Library.

Bru, E., Stephens, P., \& Torsheim, T. (2002). Students' perceptions of class management and reports of their own misbehavior. Journal of School Psychology, 40(4), 287-307. doi: http://dx.doi.org/10.1016/S0022-4405(02)00104-8

Burden, P. R. (1980). Teachers' perceptions of the characteristics and influences on their personal and professional development. (ERIC Document Reproduction Service NO. ED 198 087). Manhattan, KS: Kansas State University. 
Burden, P. R. (1990). Teacher development. In W. R. Houston, M. Haberman, \& J. P. Sikula (Eds.), Handbook of research on teacher education (pp. 311-328). New York: Macmillan.

Byman, R., \& Kansanen, P. (2008). Pedagogical thinking in a student's mind: A conceptual clarification on the basis of self-determination and volition theories. Scandinavian Journal of Educational Research, 52(6), 603-621.

doi: http://dx.doi.org/10.1080/00313830802497224

Clayson, D. E. (2009). Student evaluations of teaching: Are they related to what students learn? A meta-analysis and review of the literature. Journal of Marketing Education, 31(1), 16-30. doi: http://dx.doi.org/10.1177/0273475308324086

Cohen, L., Manion, L., \& Morrison, K. (2001). Research methods in education. London: Routledge Falmer.

Cohen, L., Manion, L., \& Morrison, K. (2010). A guide to teaching practice (Rev. 5th ed.). London: Routledge.

Conway, P. F., \& Clark, C. M. (2003). The journey inward and outward: A re-examination of Fuller's concerns-based model of teacher development. Teaching and Teacher Education, 19(5), 465-482. doi: http://dx.doi.org/10.1016/S0742-051X(03)00046-5

Cothran, D. J., Kulinna, P. H., \& Garrahy, D. A. (2003). „This is kind of giving a secret away ...": Students' perspectives on effective class management. Teaching and Teacher Education, 19(4), 435-444.

doi: http://dx.doi.org/10.1016/S0742-051X(03)00027-1

Deci, E. L., \& Ryan, R. M. (1985). The general causality orientations scale: Selfdetermination in personality. Journal of Research in Personality, 19(2), 109-134. doi: http://dx.doi.org/10.1016/0092-6566(85)90023-6

De Jong, R., \& Westerhof, K. J. (2001). The quality of student ratings of teacher behaviour. Learning Environments Research, 4(1), 51-85. doi: http://dx.doi.org/10.1023/A:1011402608575

Den Brok, P., Wubbels, T., Veldman, I., \& Van Tartwijk, J. (2009). Perceived teacherstudent interpersonal relationships in Dutch multi-ethnic classes. Educational Research and Evaluation, 15(2), 119-135. doi: http://dx.doi.org/10.1080/13803610902784303

Doll, B., Spies, R. A., LeClair, C. M., Kurien, S. A., \& Foley, B. P. (2010). Student perceptions of classroom learning environments: Development of the ClassMaps survey. School Psychology Review, 39(2), 203-218.

Dowell, D. A., \& Neal, J. A. (1982). A selective review of the validity of student ratings of teaching. The Journal of Higher Education, 53(1), 51-62. doi: http://dx.doi.org/10.2307/1981538

Duffield, J., Allan, J., Turner, E., \& Morris, B. (2000). Pupils voices on achievement: An alternative to the standards agenda. Cambridge Journal of Education, 30(2), 263-274. doi: http://dx.doi.org/10.1080/713657150

Eraut, M. (1994). Developing professional practice and competence. London: Falmer Press.

Ericsson, K. A. (Ed.). (1996). The road to excellence. The acquisition of expert performance in the arts and sciences, sports and games. New Jersey: Lawrence Erlbaum Associates. 
Fauth, B., Decristan, J., Rieser, S., Klieme, E., \& Büttner, G. (2014). Student ratings of teaching quality in primary school: Dimensions and prediction of student outcomes. Learning and Instruction, 29, 1-9. doi: http://dx.doi.org/10.1016/j.learninstruc.2013.07.001

Fraser, B. (1989). Twenty years of classroom climate work: Progress and prospect. Journal of Curriculum Studies, 21(4), 307-327. doi: http://dx.doi.org/10.1080/0022027890210402

Fuller, F. F. (1969). Concerns of teachers: A developmental conceptualization. American Educational Research Journal, 6(2), 207-226. doi: http://dx.doi.org/10.3102/00028312006002207

Fuller, F. F., \& Bown, O. H. (1975). Becoming a teacher. In K. Ryan (Ed.), Teacher education (pp. 25-52). Chicago, IL: University of Chicago Press.

Gagne, R. M., \& Driscoll, M. P. (1992). Õppimise olemus ja õpetamine. Tartu: Tartu Ülikool.

Good, T. L., \& Brophy, J. E. (1995). Contemporary educational psychology (5th ed.). New York: Longman Publishers.

Huberman, M. (1992). Teacher development and instructional mastery. In A. Hargreaves \& M. G. Fullan (Eds.), Understanding teacher development (pp. 122-142). New York: Teachers College Press.

Hudelson, E. (1951). The validity of student rating of instructors. School and Society, 73, 265-266.

Huges, J. N., Wu, J. Y., Kwok, O.-M., Villarreal, V., \& Johnson, A. Y. (2012). Indirect effects of child reports of teacher-student relationship on achievement. Journal of Educational Psychology, 104(2), 350-365. doi: http://dx.doi.org/10.1037/a0026339

Kagan, D. M. (1992). Professional growth among preservice and beginning teachers. Review of Educational Research, 62(2), 129-169. doi: http://dx.doi.org/10.3102/00346543062002129

Katz, I., Kaplan, A., \& Gueta, G. (2010). Students' needs, teachers' support, and motivation for doing homework: A cross-sectional study. Journal of Experimental Education, 78(2), 246-267. doi: http://dx.doi.org/10.1080/00220970903292868

Kember, D., \& Leung, D. Y. P. (2011). Disciplinary differences in student ratings of teaching quality. Research in Higher Education, 52(3), 278-299. doi: http://dx.doi.org/10.1007/s11162-010-9194-z

Kitsing, M., Täht, K., \& Kukemelk, H. (2015). Kooli mikrokliima: õpetajate toetav käitumine ja õpilaste tulemuslikkus. Eesti Haridusteaduste Ajakiri, 3(1), 127147. doi: http://dx.doi.org/10.12697/eha.2015.3.1.06

Krips, H. (2008). Teachers' behaviours in forms 5 to 9 and forms 10 to 12 classrooms. In J. Mikk, M. Veisson, \& P. Luik (Eds.), Reforms and innovations in Estonian education (pp. 139-153). Frankfurt am Main: Peter Lang Verlag.

Krips, H. (2011). Oppetajate suhtlemiskompetentsus ja suhtlemisoskused (doktoritöö). Tartu Ülikool, Tartu. Külastatud aadressil dspace.ut.ee/bitstream/handle/10062/17218/krips_heiki.pdf.

Krull, E. (2000). Pedagoogilise psühholoogia käsiraamat. Tartu: Tartu Ülikooli Kirjastus. Krull, E., Leijen, Ä., Lepik, M., Mikk, J., Talts, L., \& Õun, T. (2013). Õpetajate professionaalne areng ja selle toetamine. Projekti „Õpetajate professionaalne areng ja 
selle toetamine" tulemused õpetajakoolituse teenistuses. Artiklite kogumik. Tartu: Eesti Ülikoolide Kirjastus.

Kunter, M., \& Baumert, J. (2006). Who is the expert? Construct and criteria validity of student and teacher ratings of instruction. Learning Environments Research, 9(3), 231-251. doi: http://dx.doi.org/10.1007/s10984-006-9015-7

Kunter, M., Frenzel, A., Nagy, G., Baumert, J., \& Pekrun, R. (2011). Teacher enthusiasm: Dimensionality and context specificity. Contemporary Educational Psycho$\log y$, 36(4), 289-301. doi: http://dx.doi.org/10.1016/j.cedpsych.2011.07.001

Kunter, M., Tsai, Y.-M., Klusmann, U., Brunner, M., Krauss, S., \& Baumert, J. (2008). Students' and mathematics teachers' perceptions of teacher enthusiasm and instruction. Learning and Instruction, 18(5), 468-482.

doi: http://dx.doi.org/10.1016/j.learninstruc.2008.06.008

Long, J. F., \& Hoy, A. W. (2006). Interested instructors: A composite portrait of individual differences and effectiveness. Teaching and Teacher Education, 22(3), 303-314. doi: http://dx.doi.org/10.1016/j.tate.2005.11.001

Lüdtke, O., Robitzsch, A., Trautwein, U., \& Kunter, M. (2009). Assessing the impact of learning environments: How to use student ratings of classroom or school characteristics in multilevel modeling. Contemporary Educational Psychology, 34(2), 120-131. doi: http://dx.doi.org/10.1016/j.cedpsych.2008.12.001

Marsh, H. W. (2007). Students' evaluations of university teaching: A multidimensional perspective. In R. Perry \& J. C. Smart (Eds.), The scholarship of teaching and learning in higher education: An evidence-based perspective (pp. 319-383). New York: Springer. doi: http://dx.doi.org/10.1007/1-4020-5742-3_9

Marsh, H. W., \& Roche, L. A. (1997). Making students' evaluations of teaching effectiveness effective: The critical issues of validity, bias, and utility. American Psychologist, 52(11), 1187-1197. doi: http://dx.doi.org/10.1037/0003-066X.52.11.1187

McDonald, F. J. (1982). A theory of the professional development of teachers. Paper presented at the annual meeting of the American Educational Research Association, New York.

McKeachie, W. J. (1997). Student ratings: The validity of use. American Psychologist, 52(11), 1218-1225. doi: http://dx.doi.org/10.1037/0003-066X.52.11.1218

McKeachie, W. J., Lin, Y. G., \& Mann, W. (1971). Student rating of teacher effectiveness: Validity studies. American Educational Research Journal, 8(3), 435-445. doi: http://dx.doi.org/10.3102/00028312008003435

McPherson, M. A. (2006). Determinants of how students evaluate teachers. The Journal of Economic Education, 37(1), 3-20. doi: http://dx.doi.org/10.3200/JECE.37.1.3-20

McPherson, M. A., Todd Jewell, R., \& Kim, M. (2009). What determines student evaluation scores? A random effects analysis of undergraduate economics classes. Eastern Economic Journal, 35(1), 37-51.

doi: http://dx.doi.org/10.1057/palgrave.eej.9050042

Nash, R. (1976). Teacher expectations and pupil learning. London: Routledge and Kegan Paul.

Nash, R. (2012). Teacher expectations and pupil learning. London: Routledge Library Editions: Education. 
Okas, A., Van der Schaaf, M., \& Krull, E. (2013a). Novice and experienced teachers' personal practical knowledge in planning lessons. In J. Mikk, M. Veisson, \& P. Luik (Eds.), Estonian studies in education (pp. 27-43). Frankfurt am Main: Peter Lang Verlag.

Okas, A., Van der Schaaf, M., \& Krull, E. (2013b). Algajate ja kogenud õpetajate praktilise teadmise avaldumine tunnisündmuste kommenteerimisel stimuleeritud meenutuse meetodil. Eesti Haridusteaduste Ajakiri, 1, 25-45. doi: http://dx.doi.org/10.12697/eha.2013.1.03

Okas, A., Van der Schaaf, M., \& Krull, E. (2014). Novice and experienced teachers views on professionalism. Trames: Journal of the Humanities and Social Sciences, 18(68/63), 327-344. doi: http://dx.doi.org/10.3176/tr.2014.4.02

Palmer, D. J., Stough, L. M., Burdenski, T. K., \& Gonzales, M. (2005). Identifying teacher expertise: An examination of researchers' decision making. Educational Psychologist, 40(1), 13-25. doi: http://dx.doi.org/10.1207/s15326985ep4001_2

Pham, G., Koch, T., Helmke, A., Schrader, F.-W., Helmke, T., \& Eid, M. (2012). Do teachers know how their teaching is perceived by their pupils? 4th World Conference on Educational Sciences (WCES-2012-02-05), February 2012, Barcelona, Spain. Procedia - Social and Behavioral Sciences, 46, 3368-3374. doi: http://dx.doi.org/10.1016/j.sbspro.2012.06.068

Pigge, F. L., \& Marso, R. N. (1997). A seven year longitudinal multi-factor assessment of teaching concerns development through preparation and early years of teaching. Teaching and Teacher Education, 13(2), 225-235. doi: http://dx.doi.org/10.1016/S0742-051X(96)00014-5

Remmers, H. H. (1934). Reliability and halo-effect of high school and college students' judgments of their teachers. Journal of Applied Psychology, 18(5), 619630. doi: http://dx.doi.org/10.1037/h0074783

Rezler, A. G. (1965). The influence of needs upon the student's perception of his instructor. The Journal of Educational Research, 58(6), 282-286. doi: http://dx.doi.org/10.1080/00220671.1965.10883223

Ruus, V.-R., Veisson, M., Leino, M., Ots, L., Pallas, L., Sarv, E.-S., \& Veisson, A. (2007). Students well-being, coping, academic success, and school climate. Social Behavior and Personality, 35(7), 919-936. doi: http://dx.doi.org/10.2224/sbp.2007.35.7.919

Ryan, M. R., \& Deci, E. L. (2000). Intrinsic and extrinsic motivations: Classic definitions and new directions. Contemporary Educational Psychology, 25(1), 54-67. doi: http://dx.doi.org/10.1006/ceps.1999.1020

Scriven, M. (1988). The validity of student ratings. Instructional Evaluation, 9, 5-18.

Skaalvik, E. M., \& Skaalvik, S. (2013). School goal structure: Associations with students' perceptions of their teachers as emotionally supportive, academic selfconcept, intrinsic motivation, effort, and help-seeking behavior. International Journal of Educational Research, 61, 5-14. doi: http://dx.doi.org/10.1016/j.ijer.2013.03.007

Spooren, P., Brockx, B., \& Mortelmans, D. (2013). On the validity of student evaluation of teaching: The state of the art. Review of Educational Research, 83(4), 598-642. doi: http://dx.doi.org/10.3102/0034654313496870 
Stehle, S., Spinath, B., \& Kadmon, M. (2012). Measuring teaching effectiveness: Correspondence between students' evaluations of teaching and different measures of student learning. Research in Higher Education, 53(8), 888-904.

doi: http://dx.doi.org/10.1007/s11162-012-9260-9

Swennen, A., Jörg, T., \& Korthagen, F. (2004). Studying student teachers' concerns, combining image-based and more traditional research techniques. European Journal of Teacher Education, 27(3), 265-283.

doi: http://dx.doi.org/10.1080/0261976042000290796

Van der Schaaf, M. F. (2005). Construct validation of teacher portfolio assessment. Procedures for improving teacher competence assessment illustrated by teaching students research skills (Doctoral dissertation). Utrecht University, Utrecht.

Wagner, W., Göllner, R., Helmke, A., Trautwein, U., \& Lüdtke, O. (2013). Construct validity of student perceptions of instructional quality is high, but not perfect: Dimensionality and generalizability of domain-independent assessments. Learning and Instruction, 28, 1-11. doi: http://dx.doi.org/10.1016/j.learninstruc.2013.03.003

Wang, M. C., Haertel, G. D., \& Walberg, H. J. (1993). Synthesis of research: What helps students learn? Educational Leadership, 51(4), 74-79.

Watzke, J. L. (2007). Longitudinal research on beginning teacher development: Complexity as a challenge to concerns-based stage theory. Teaching and Teacher Education, 23(1), 106-122. doi: http://dx.doi.org/10.1016/j.tate.2006.04.001

Way, N., Reddy, R., \& Rhodes, J. (2007). Students' perceptions of school climate during the middle school years: Associations with trajectories of psychological and behavioral adjustment. American Journal of Community Psychology, 40(3-4), 194-213. doi: http://dx.doi.org/10.1007/s10464-007-9143-y

Wentzel, K. R. (1997). Student motivation in middle school: The role of perceived pedagogical caring. Journal of Educational Psychology, 89(3), 411-419. doi: http://dx.doi.org/10.1037/0022-0663.89.3.411

Wentzel, K. R. (1998). Social relations and motivation in middle school: The role of parents, teachers, and peers. Journal of Educational Psychology, 90(2), 202-209. doi: http://dx.doi.org/10.1037/0022-0663.90.2.202

White, B. (2009). Student perceptions of what makes good teaching. Paper presented at „Teacher education crossing borders: Cultures, contexts, communities and curriculum", the annual conference of the Australian Teacher Education Association (ATEA), Albury, 28 June - 1 July.

Witcher, A. E., Onwuegbuzie, A. J., \& Minor, I. C. (2001). Characteristics of effective teachers: Perceptions of preservice teachers. Research in the Schools, 8(2), 45-57. 
Lisa 1. Õpilasküsimustik (Van der Schaaf, 2005)

Skaala 1-4, kus 1 - üldse mitte, 2 - pigem mitte, 3 - pigem jah, 4 - jah, kindlasti.

\begin{tabular}{|c|c|c|}
\hline Väited & Keskmine & $S D$ \\
\hline 1. Tunni eesmärk on selge & 2,85 & 0,88 \\
\hline 2. Meil on rahuldavad tingimused töö tegemiseks & 3,23 & 0,56 \\
\hline 3. Tunni ülesannete sisu on selge & 3,05 & 0,80 \\
\hline 4. Tunni ülesanded on rasked & 2,32 & 0,85 \\
\hline 5. Õpetaja annab praktilisi juhiseid & 2,66 & 0,84 \\
\hline $\begin{array}{l}\text { 6. Õpetaja kontrollib regulaarselt, kas me saame } \\
\text { ülesandest aru }\end{array}$ & 2,66 & 0,96 \\
\hline 7. Õpetaja annab selgeid juhiseid & 2,76 & 1,0 \\
\hline 8. Õpetaja on entusiastlik & 2,49 & 1,0 \\
\hline 9. Õpetaja on valmis selgitama mitu korda & 2,93 & 0,87 \\
\hline 10. Õpetajal on meisse usku & 2,84 & 0,79 \\
\hline 11. Õpetajal on suured ootused & 3,04 & 0,96 \\
\hline 12. Õpetaja on meist huvitatud & 2,42 & 0,99 \\
\hline 13. Õpetaja näitab üles huvi meie ideede vastu & 2,06 & 0,93 \\
\hline $\begin{array}{l}\text { 14. Õpetaja paneb tähele ja toetab õpilastevahelist } \\
\text { suhtlemist }\end{array}$ & 3,00 & 0,75 \\
\hline $\begin{array}{l}\text { 15. Õpetaja kontrollib, kas me tegelikult töötame tunni } \\
\text { ülesannete kallal }\end{array}$ & 3,55 & 0,59 \\
\hline
\end{tabular}




\title{
Students' perception of their teachers' behaviour in the classroom and its coherence with teachers' own understandings
}

\author{
Anne Okasa ${ }^{a}$, Marieke van der Schaaf ${ }^{b}$, Edgar Krull ${ }^{a}$ \\ ${ }^{a}$ Institute of Education, University of Tartu \\ ${ }^{b}$ Department of Education, Utrecht University
}

\begin{abstract}
Summary
From the 1920s onwards student evaluations as a method of assessing the effectiveness of teachers' work have been a topic of research (Dowell \& Neal, 1982; Fauth et al., 2014; Hudelson, 1951; Kember \& Leung, 2011; McKeachie, 1997; McKeachie et al., 1971; Remmers, 1934; Rezler, 1965; Stehle et al., 2012; Way et al., 2007). For example, research is focused on how students evaluate their teachers' ability to motivate them and include them in different activities, structure lessons and manage classwork in general (Wagner et al., 2013). Different authors have examined the eligibility of this method - students' evaluations in depth (Anderson \& Walberg, 1974; Fauth et al., 2014; Fraser, 1989; Kunter \& Baumert, 2006; McKeachie et al., 1971; Scriven, 1988).

This study aims to investigate how basic education students perceive their teachers' behaviour in the classroom and what differences the students' perceive of novice and experienced teachers' behavioural patterns.
\end{abstract}

\section{Theoretical background}

The literature on studies of student ratings of teaching has been characterised as extensive, contradictory and highly variably concerning the quality (Lüdtke et al., 2009). While the feedback from university students on subject courses taken is seen as a natural evaluation method of teaching quality in higher education (Marsh, 2007), the use of feedback from school students as a research method is considered subjective, i.e. it is highly dependent on whether students like or dislike their teachers (De Jong \& Westerhof, 2001; Kunter \& Baumert, 2006).

At the same time, several researchers claim that although students' evaluations of their teachers are not identical to the teachers' real behaviour,

1 Institute of Education, University of Tartu, Salme 1a, 50103 Tartu, Estonia; anneokas@ut.ee 
these evaluations - even with a certain degree of subjectivity - still reflect the reality (Krips, 2008, 2011). Many researchers advise paying more attention to studying teacher behaviour and recommend using student evaluations in addition to other assessment methods (Den Brok et al., 2009; Duffield et al., 2000; Fauth et al., 2014).

Numerous studies show that the quality of teachers' own evaluation of their teaching is not always adequate (Pham et al., 2012). Furthermore, teachers typically do not really know how students perceive their activity (teaching) in the classroom. Receiving students' feedback and constructive reflection could allow teachers to discover new viewpoints in their teaching (ibid.).

Becoming a successful teacher, one who can work with children of different ages, greatly depends on how well someone is able to adapt to students' expectations and behave according to their ideas of a good teacher (Krull, 2000). A modern definition of the learning-teaching process is described as creating a stimulating and safe learning environment for students. This means that teachers base their work on students' needs and interests (Byman \& Kansanen, 2008). In order to be liked by students a teacher must have authority in the eyes of her or his students. According to the literature, a teacher must first have certain character traits that are generally required to guide people: cheerfulness, friendliness, sincerity, an ability to control their emotions and other characteristics indicative of good mental health and personal emotional intelligence. Students often have quite clear expectations as to what makes a good teacher and their expectations depend on their experience at school and their cultural background (Krull, 2000).

To summarise, students want to see their teacher as an authoritive figure in the classroom who can create a predictable structure for working, react decisively to students' unacceptable behaviour and understand students individually and the class as a whole (Krull, 2000).

According to Fuller (1969), one of the relevant features of teachers' professional development is their ability to recognise problems. Using data obtained directly from 50 student teachers and indirectly from other databases and reports of similar surveys, Fuller inferred a three-stage model of teacher development that focused on teachers' concerns. In the early phase, the main concerns regard classroom management in order to control a class of pupils. More generally, they are concerned with self-adequacy. As a teacher becomes more competent and his/her self-confidence grows, the emphasis shifts to more serious concerns related to teaching and learning. Another approach to describe developmental stages of teachers is a 
model of teachers' professional thinking and decision-making by Berliner (1986, 1994). This model points out that the development of teachers' professional decision making starts from following context-free rules as the lowest level, with only a small fraction of teachers reaching the highest, socalled expert teacher level. According to Good and Brophy (1995) there are two things which separate a novice and a professional. A professional can classify problem situations and events more effectively and more swiftly by moving smoothly from one level of generalisation to another to find the right pedagogic solution. A professional teacher is faster than a novice in determining whether misbehaviour is caused by problems relating to the student's personality or simply by e.g. hooliganism. In addition, professional teachers know many practical standard solutions, often honed to perfection, which they apply with skill and success.

\section{The empirical study}

The research questions were:

1. How do basic education students (aged 12 to 16) perceive their teachers' behaviour during activities/instruction in the classroom and how does this behaviour of novice and experienced teachers differ as perceived by their students?

2. What connections can be made between what the students perceive and the teachers' own views of their professionalism?

314 Estonian basic school students (Grades 6-9) and their twenty teachers (10 novice and 10 experienced) participated in the study. A questionnaire (Van der Schaaf, 2005) was used to collect feedback from students on the behaviour (activity) of their teachers in the classroom. The students' perceptions were compared with ideas on teaching drawn from reflective essays of teachers' (published in Okas et al., 2014) and interviews (published in Okas et al., 2013b).

The comparison of the students' perceptions with the teachers' ideas was implemented by a two-fold procedure: step one, the teacher statements that matched with, or were related to, 15 questions in the students' questionnaire were identified and step two, the teachers' ideas on specific topics were compared with the students' questionnaire replies.

The analysis of the data drawn from the students' questionnaires showed that students' perceptions of their teachers' behaviour depended on the teachers' work experience - experienced teachers received higher evaluations than novice teachers. Students felt more confident in the classes 
of experienced teachers in that they had satisfactory studying conditions in the classroom. Since there was a noticeable difference between the evaluations given to novice and experienced teachers, one issue was probably the discipline. In the students' perception, experienced teachers were more enthusiastic than novice teachers; with higher expectations in students, showing greater interest in their students and in their ideas, and having more faith in students than novice teachers. Compared to novices, experienced teachers gave more practical and clearer instructions. According to the students they were also more willing to repeat explanations than novices. Experienced teachers paid more supportive attention to contacts between students than novice teachers. However, students of experienced teachers were more positive about teachers' checks for understanding, and a sense of control was more prevalent in experienced teachers' classes. Experienced teachers set the objective of the lesson more clearly than novice teachers. The clarity of tasks given in lessons was rated more highly in experienced teachers' classes.

The comparison of the students' perceptions of teachers' behaviour with statements from the teachers' reflective writings and aspects that teachers mentioned in interviews revealed that there was a good match between the perceptions on both sides. Students were able to perceive the moments during novice teachers' lessons when the teachers felt unsure of themselves. The experienced teachers named a number of different aspects related to supervising the students, presenting them as their strengths. Students' feedback on teachers' behaviour can serve as an indicator of teachers' professionalism.

\section{Acknowledgements}

Greatest thanks go to the teachers and their students who participated in this study. We would also like to express our gratitude to the reviewers for their helpful suggestions. This article was supported by the ESF Project No. 1.2.0401.09-0070. Doctoral School of Educational Sciences.

Keywords: student evaluations, teachers' behaviour, teacher professionalism, novice teachers, experienced teachers 